\title{
AGRICULTURE, METEOROLOGY AND WATER QUALITY IN IRELAND: A REGIONAL EVALUATION OF PRESSURES AND PATHWAYS OF NUTRIENT LOSS TO WATER
}

\author{
R.P.O. Schulte, K. Richards, K. Daly, I. Kurz, E.J. McDonald and \\ N.M. Holden
}

\begin{abstract}
The main environmental impact of Irish agriculture on surface and ground water quality is the potential transfer of nutrients to water. Soil water dynamics mediate the transport of nutrients to water, and these dynamics in turn depend on agro-meteorological conditions, which show large variations between regions, seasons and years. In this paper we quantify and map the spatio-temporal variability of agro-meteorological factors that control nutrient pressures and pathways of nutrient loss. Subsequently, we evaluate their impact on the water quality of Irish rivers. For nitrogen, pressure and pathways factors coincide in eastern and southern areas, which is reflected in higher nitrate levels of the rivers in these regions. For phosphorus, pathway factors are most pronounced in north-western parts of the country. In south-eastern parts, high pressure factors result in reduced biological water quality. These regional differences require that farm practices be customised to reflect the local risk of nutrient loss to water. Where pathways for phosphorus loss are present almost year-round - as is the case in most of the north-western part of the country- build-up of pressures should be prevented, or ameliorated where already high. In south-eastern areas, spatio-temporal coincidence of nutrient pressures and pathways should be prevented, which poses challenges to grassland management.
\end{abstract}

R.P.O. Schulte (corresponding author; e-mail: rschulte@johnstown.teagasc.ie), K. Richards, K. Daly and E.J. McDonald, Teagasc, Johnstown Castle Environmental Research Centre, Wexford; I. Kurz, Teagasc, Rural Economy Research Centre, Athenry;

N.M. Holden,

Department of Biosystems Engineering, University College

Dublin, Earlsfort

Terrace, Dublin 2.

Received 20 January 2005. Accepted 13 September 2005. Published 31 July 2006.

\section{INTRODUCTION \\ WATER QUALITY IN IRELAND}

The impact of Irish agriculture on water quality is at the heart of the debate on the use and management of Ireland's rural environment. The quality of Irish surface waters is reasonably good by European standards, with over $69 \%$ of Irish rivers classified as 'unpolluted' (Toner et al. 2005). The main threat to water quality comes from nutrient enrichment, in particular by nitrogen (in the form of nitrate) and phosphorus (P), which may lead to eutrophication and subsequent changes in the aquatic ecology, and, in extreme cases, fish kills (Environmental Protection Agency 2004). Although median concentrations of nitrate have been below the drinking water limit of $11.3 \mathrm{mg}^{-1}$ of nitrate-nitrogen in most rivers, and have stabilised, or even slightly decreased since the late 1990s (McGarrigle et al. 2002; Neill 2004), the threshold concentration above which nitrates contribute to eutrophication is likely to be much lower (Environmental Protection Agency 2004). As a result, the potential contribution of nitrates to eutrophication cannot be ignored. Phosphorus concentrations have posed a more serious challenge to water quality, with median molybdate reactive $\mathrm{P}$ concentrations frequently breaching the standard for eutrophication, $0.03 \mathrm{mg} 1^{-1}$, in many rivers; however, the frequency of these breaches has shown a downward trend in recent years (Environmental Protection Agency 2004).

\section{CONCEPTUALISING RISKS OF NUTRIENT LOSS}

Agriculture is estimated to contribute significantly to the eutrophication of Irish rivers and estuaries, with $70 \%$ of phosphorus loads and $82 \%$ of nitrogen loads, respectively, attributed to agricultural sources (Environmental Protection Agency 2004; Stapleton et al. 2000). The loss of nutrients from farms, and the subsequent transport to water, has been the subject of numerous studies, both in Ireland and internationally. A full review of the processes involved is outside the scope of this paper, but the risk of nutrient loss to water can be summarised with a pressure-pathway-receptor model (Ansell 


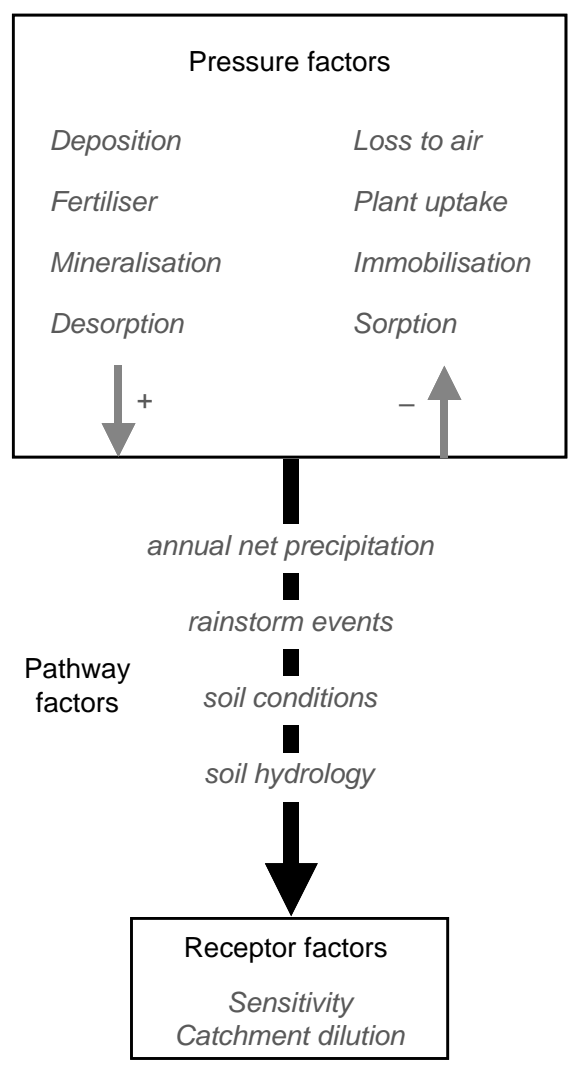

Fig. 1- Conceptual diagram of risk of nutrient loss. Risk occurs when pressures from nutrient sources, pathways for nutrient transport and sensitivity of the receptor coincide.

and Wharton 1992; Haygarth et al. 2005), in which the environmental risks of nutrient loss to water are highest where pressure and transport mechanisms coincide, and the receptor is sensitive to changes in the nutrient concentrations in water. We present a diagram showing this concept in Fig. 1.

Pressures of nutrient loss can be defined by the balance between inputs and outputs of nutrients, i.e. fertiliser and organic nutrient inputs, atmospheric deposition and/or mineralisation of nitrogen and desorption of phosphorus on the one hand, and plant uptake, losses to air and immobilisation of nitrogen and sorption of phosphorus on the other hand (Heathwaite et al. 2003). For high nutrient pressures to pose a significant risk to water quality, transport pathways have to be present in the form of percolation or overland flow, and the ecology of the receiving water body must be sensitive to the subsequent changes in nutrient levels.

\section{OBJECTIVES}

In this paper we evaluate regional, seasonal and between-year variation in the risk of nutrient losses from Irish agriculture to water, in response to spatial and temporal patterns of the most important pressure and pathway factors. Pressure factors taken into consideration were 1) soil nutrient levels, 2) land use, 3 ) the length of the grass growth season and 4) droughts. Pathways factors included in this study were 1) soil drainage capacity, 2) the quantity and seasonality of net rainfall, 3) rainfall intensity and 4) the number of trafficable days. This study considered nutrient losses from agriculture only and, within this category, has been confined to losses from field sources, which are considered to play an essential role in surface water pollution (Tunney et al. 2000; Jordan et al. 2005; McGarrigle 2005).

First, the importance of each of these pressures and pathways to nutrient loss, as well as their dependence on agro-meteorological conditions, will be briefly reviewed. Subsequently, this paper sets out to quantify the spatial and temporal distribution of each of these pressure and pathway factors. The interdependence and interactions between all factors are then discussed.

It is important to note that this paper evaluates large-scale, regional patterns of pressures and pathways of nutrient loss. The low spatial resolution of some of the input variables prohibited analysis at finer resolutions (e.g. at catchment-scale), and the geographic distributions presented in this paper should therefore not be considered discrete delineations of high and lowrisk areas.

\section{BACKGROUND}

\section{PRESSURE FACTOR: SOIL NUTRIENT LEVELS}

Agronomic advice recommends a higher target level for soil $\mathrm{P}$ for more intensive livestock enterprises (Coulter 2004). High soil test P (STP) levels are related directly to high $\mathrm{P}$ desorption from Irish soil types (Daly et al. 2001) and to increased losses of $\mathrm{P}$ in laboratory flume and column experiments (Doody 2004). The effect of high STP levels on P loss in overland flow has also been found at plot (Pote et al. 1999), field (Kurz et al. 2005) and catchment scale (Jordan et al. 2005; Daly et al. 2002). Therefore, phosphorus applications represent not only a direct risk of P-loss through overland flow (Nash et al. 2000), but also contribute to the build-up of soil $\mathrm{P}$, which in turn impacts on risk.

For nitrogen, surplus may partially be stored in the soil through immobilisation, but there is no evidence to suggest that this reduces nitrogen losses significantly under Irish conditions. Alternatively, an additional supply of nitrogen can be provided by the release of soil nitrogen through mineralisation. In Ireland, the rate of net mineralisation (i.e. the 
difference between gross mineralisation and immobilisation) was observed to range from $56 \mathrm{~kg}$ to $220 \mathrm{~kg} \mathrm{~N} \mathrm{ha}^{-1} \mathrm{yr}^{-1}$ as a function of soil texture, soil depth, organic matter content and soil water status (O’Connell and Humphreys 2005).

\section{PRESSURE FACTOR: LAND USE}

In the case of nitrogen, land use patterns have been identified as a main cause of regional differences in water quality. Tillage farming adds to the pressures of nutrient loss: Ryan and Fanning (1999) measured leaching in lysimeters for a range of soil types, and found nitrate concentrations to be $60 \%$ higher, on average, under tillage compared with cut grass. Similarly, both Webster and Dowdell (1986) and Thomsen and Christensen (1998) observed higher nitrate losses under tillage than grassland. In tillage systems, the ploughing of soil stimulates mineralisation of soil organic matter, releasing nitrogen (Addiscot 1996). In addition, land left fallow during the winter can continue to release nitrogen at a time of the year when there is no plant uptake due to the absence of a crop. The regional pressure exerted by ploughing largely overlaps with pressures from high livestock densities, and the associated higher intensities of nutrient inputs.

\section{PRESSURE FACTOR: GRASS GROWING SEASON}

The grass growing season is a pressure factor because it dictates the nature of nutrient demand and fertiliser usage on farms as well as the potential for nutrient uptake by the growing grass crop. Shorter growing seasons may increase nutrient pressures as the process of nutrient transport is competing with nutrient uptake for a shorter part of the year (Scholefield et al. 1991). For example, Ryan and Fanning (1999) observed increased nitrate leaching with autumn slurry application compared with spring application. At the same time, longer growth seasons may encourage application of fertiliser at times of year when nutrient utilisation by growing grass declines to levels that, though still economically sustainable, are less efficient in environmental terms, with associated risks of nutrient losses (e.g. Beever et al. 1986; Rearte 2005).

As a permanent crop, grass has a particularly long growing season. It has been established that grass growth commences as soon as temperatures rise above $3^{\circ} \mathrm{C}$ to $6^{\circ} \mathrm{C}$ (e.g. Woledge and Dennis 1982; Collins and Cummins 1996; Burke et al. 2004). Connaughton (1973) calculated the median dates for the beginning and the end of the grass growing season using a soil temperature threshold of $6^{\circ} \mathrm{C}$, and the resulting map of the duration of the growing season has been published by both Collins and Cummins (1996) and Burke et al. (2004). However, this map does not account for the fact that, even at high temperatures, growth is restricted in anaerobic soil conditions (Brereton and Hope-Cawdery 1988; Burke et al. 2004).

\section{PRESSURE FACTOR: DROUGHTS}

The growing season is also influenced by the occurrence of drought. Recent research suggests that droughts during summer contribute to nitrate concentrations in groundwater. Holden and Brereton (2002) showed that under recent (196190) climatic conditions, droughts had only small agronomic effects on grass productivity, and that these effects were confined to areas along the east coast only, with associated annual productivity losses of less than $400 \mathrm{~kg}$ dry matter ha ${ }^{-1}$. As this reduces plant uptake, nitrogen fertilisation should be adjusted accordingly (Coulter 2004). More importantly, though, numerous studies have observed a link between drought and increased nitrate leaching (Webster and Dowdell 1984; Garwood and Ryden 1986; Burt 2003). Tyson et al. (1997) and Richards (1999) found a strong, linear increase of nitrate levels in groundwater with increasing SMDs during the previous summer months. They explained this by a restriction of grass growth, which limits $\mathrm{N}$ uptake by grass; thus an accumulation of unused fertiliser $\mathrm{N}$ could build up in the soil, which may then be leached by subsequent soil re-wetting. Garwood and Williams (1967) found a decrease in the quantity of fine grass roots during drought periods, a process that can release large quantities of $\mathrm{N}$ and also further restrict plant growth. Upon re-wetting, the roots grew again, but not to the same extent as before the drought. Ryan et al. (1998) also observed an increase in soil inorganic $\mathrm{N}$ in an Irish forest soil after a drought in 1992. This was attributed to both the restriction in plant uptake and also an increase in mineralisation after soil re-wetting. Similarly, Herlihy (1979) observed that drought increased the amount of $\mathrm{N}$ mineralised in a number of Irish soils compared with constant soil moisture levels.

\section{PATHWAY FACTOR: SOIL DRAINAGE}

Nitrate is highly mobile in soil water, as it is a negatively charged anion. Unless nitrate is taken up and utilised by plant roots, it is easily leached when a soil at field capacity receives more water than required for evapotranspiration. Once nitrate is leached below the rooting zone, it is normally lost from an agricultural system (Whitehead 1995). Risk of nitrogen loss to water is therefore greater on well-drained soils.

By contrast, phosphorus is largely immobile, as it is easily adsorbed by soils that are not P-saturated, 
and subsequently accumulates in the very top of the soil profile (Tiessen et al. 1983). As a result, phosphorus is generally not transported through the soil matrix. Instead, overland flow and preferential flow are the main pathways of phosphorus loss from soils (Haygarth and Jarvis 1997; Uusitalo et al. 2001).

\section{PATHWAY FACTOR: ANNUAL AMOUNTS OF NET RAINFALL}

Risk of nutrient losses to water is generally greatest when soils are near field-capacity or saturation, and any further precipitation leads to water surpluses and either sub-surface drainage or overland flow. However, rare incidents of infiltration excess overland flow, which is triggered by the rainfall rate exceeding the infiltration capacity of the soil, have been observed by Kurz (2002) and Doody (2004). Average precipitation ranges from just under $800 \mathrm{~mm}$ per annum on the east coast, to over $1200 \mathrm{~mm}$ on the west coast, with the highest annual rainfall, between $1600 \mathrm{~mm}$ and $2800 \mathrm{~mm}$, recorded in the mountainous areas in the extreme west and south-west (reported in Collins and Cummins 1996). However, a substantial part of this precipitation is returned to the atmosphere through evapotranspiration. The difference between the total precipitation and the actual evapotranspiration constitutes the amount of precipitation available for subsurface drainage and overland flow, and this will be referred to as the 'net rainfall' (as distinct from 'effective' rainfall, which, depending on the subject matter studied, refers to water available either for subsurface drainage only, or for overland flow only).

Large volumes of rainfall, resulting in large volumes of drainage water, can have two effects on $\mathrm{N}$-loss to water: reducing the proportion of nitrate retained in a soil, or diluting the concentration of nitrate (Scholefield et al. 1993; Tyson et al. 1997).

\section{PATHWAY FACTOR: RAINFALL INTENSITY}

While the annual amount of net rainfall impacts on nitrate concentrations, phosphorus loss is primarily governed by the occurrence, frequency and timing of intense overland-flow events that follow intense rainstorm events. Within individual overland-flow events, higher rates of flow can be accompanied by increased phosphorus concentrations (Heathwaite and Dils 2000; Kurz et al. 2005). Doody (2004) suggested that this counterintuitive relationship could be explained by the rapid expansion of variable source areas, which increases the accessibility of freely-available $\mathrm{P}$ to overland flow. In addition, the findings of Ahuja et al. (1981) suggest that the effective depth of interaction increases with rainfall intensity. As a result of both processes, the source volume acting as a $\mathrm{P}$ source increases non-linearly with intensity.

Even though annual P loss from agricultural land to water is generally governed by few individual rainstorm events (McColl 1979; Nash and Murdoch 1997), the importance of smaller events should not be underestimated. Owing to the fact that they are much more frequent than larger storm events, their contribution to annual $\mathrm{P}$ exports may, at times, reach significant proportions (Quinton et al. 2001)

Recent work suggests that on the well-drained soils, rainfall intensity may also impact on nitrogen losses through leaching. Although Scholefield et al. (1993) concluded that the intensity of rainfall during the winter drainage period only had a small effect on the concentration of nitrate leached, heavy rainfall after fertiliser/slurry application increases the risk of nutrient loss to water. Barraclough et al. (1983) observed most nitrate leaching associated with heavy rainfall following fertiliser application to grassland in early springtime.

\section{PATHWAY FACTOR: NUMBER OF TRAFFICABLE DAYS}

Grazing and trafficking on wet soils may increase risks of nutrient loss through soil compaction, as this compromises herbage nutrient uptake and augments overland flow. In addition, extending the grazing season increases risks that nutrients, i.e. fertiliser and excreta, are deposited at times when soils are wet and when most of the rainfall is drained through either overland flow or percolation, facilitating nutrient transport.

The length of the 'grazing season' (as opposed to the growth season) has previously been computed from both the mean annual temperature and the mean annual precipitation (reported in Collins and Cummins 1996). However, this approach fails to acknowledge differences in hydrology, and hence trafficability, between soils. Such differences can be accounted for by relating trafficability to a minimum threshold SMD. In an empirical study, Earl (1997) observed a range of soil types in the UK and found that for most soils, a threshold SMD of c. $10 \mathrm{~mm}$ was required to allow traffic 'without undue sinkage ..., slippage or adhesion of soil to the tyres'.

\section{PREDICTING SOIL WATER DYNAMICS}

All of the pressure factors described above (i.e. length of the grazing season and droughts) and all of the pathway factors are governed to a large extent by soil water dynamics, either directly or indirectly. Individual soils show large differences in hydrology, i.e. the pathways through which excess water is 
drained. Moreover, precipitation is the meteorological variable showing the greatest degree of spatial and temporal variation (Hamilton et al. 1988), as a result of which large differences in soil water dynamics occur between regions, seasons and years. Regional evaluation of pressures and pathways therefore requires the quantification and prediction of the spatio-temporal patterns of soil water dynamics.

Schulte et al . (2005) formulated a robust model (the Hybrid model) that predicts soil moisture deficits for well-drained, moderately drained and poorly drained soils, requiring only readily available data for parameterisation. Well-drained soils were defined as those in which water surplus is drained instantly and, therefore, do not carry water in excess of field capacity at any time. Moderately drained soils were considered to be soils that may carry a water surplus and reach saturation on wet winter days, but that return to field-capacity on the first subsequent dry day. Poorly drained soils, having a very low drainage capacity, by definition, carry a water surplus for a number of days after winter rainfall. The Hybrid model was calibrated for Irish soils, using temporal soil moisture tension patterns observed in contrasting soils by Diamond and Sills (2001).

\section{MATERIALS AND METHODS}

\section{SOIL WATER STATUS}

Weather data from Met Éireann's thirteen synoptic weather stations were used to compute distributions of rainfall and evapotranspiration. Recently, McElwain and Sweeney (2004) showed that Irish weather has been subject to climate change, with 'rapid warming in the 1990s', and that for precipitation, there is 'evidence of a trend towards winter increases in the north-west of the country and summer decreases in the south-east', largely in line with predictions of global climate models (Holden et al. 2003). This paper assesses the impact of current meteorological conditions, and therefore only recent weather data of the last decade, i.e. from 1 January 1994 until 31 December 2003, were used.

Temporal patterns of evapotranspiration and soil moisture conditions at the weather stations were computed using the Hybrid model for soil moisture deficits (SMDs) (Schulte et al. 2005). Where daily data on radiation were not available, radiation amounts were estimated from daily sunshine hours and Julian days (Keane 2001; Schulte et al. 2005). The Hybrid model predicts SMDs from weather conditions, and soil drainage capacity.
Irish soils are spatially heterogeneous and the resolution required to map the distribution of individual soil series is not appropriate for applications at regional or national scale (Soil Survey Staff 1951). Therefore, the General Soil Map of Ireland (Gardiner and Radford 1980) was used, with soils classified as associations, i.e. spatial clusters of soil types that are commonly found together within geographical regions. In the original soil survey, individual soils were assigned to one of six drainage categories (Gardiner and Radford 1980). For the purpose of this study, this approach was simplified by assigning each of the soil associations to one of the three drainage classes used in the SMD model, based on the drainage category of the dominant mineral soil type of each soil association (J. Diamond, pers. comm.):

- well-drained soil associations: 6-10, 12-20, 23, 28, 29, 30-38;

- Moderately drained soil associations: 11, 39, 40;

- poorly drained soil associations: 1, 2, 4, 5, 21, $22,24,25,27,42-44$.

Soil associations 3, 26, 41 are located exclusively in Northern Ireland and were not considered for this study.

Ireland was subdivided into 798 cells of $10 \mathrm{~km} \times 10 \mathrm{~km}$, aligned to the National Grid of Ireland (origin: lat: $53^{\circ} 30^{\prime} 00^{\prime \prime} \mathrm{N}$; long: $8^{\circ} 00^{\prime} 00^{\prime \prime}$ $\mathrm{W})$. For each cell, the proportion of soil associations falling into the well-drained, moderately drained, and poorly drained soil drainage classes was estimated (using ESRI ${ }^{\mathrm{TM}}$ ArcView $^{\circledR}$ GIS 3.2a). Areas classified as urban areas on the General Soil Map of Ireland and areas covered by water (lakes, rivers and maritime) were categorised as 'other' and were excluded from these calculations. For example, the area of cell T02 (Wexford town) was made up of c. 37\% welldrained soil associations, $17 \%$ moderately drained soil associations and $21 \%$ poorly drained soil associations, with the remaining $25 \%$ consisting of water and urban areas. The proportion of welldrained soil associations within this cell was therefore calculated as $37 \% /(37 \%+17 \%+21 \%)=$ $49 \%$. The proportions of moderately drained and poorly drained soil associations were computed accordingly as $23 \%$ and $28 \%$, respectively.

Spatio-temporal patterns of moisture conditions were calculated by i) spatially interpolating the moisture conditions of soil associations within the individual drainage classes onto a $10 \mathrm{~km} \times 10 \mathrm{~km}$ grid by fitting tensioned splines (weight: 0.1 with 4 points tensioned) to the values at the weather stations (using ESRI ${ }^{\mathrm{TM}}$ ArcView ${ }^{\circledR}$ GIS 3.2a), and ii) deriving weighted averages for each grid cell, based on the relative proportions of soil associations falling within the three drainage classes. For example, for cell T02 


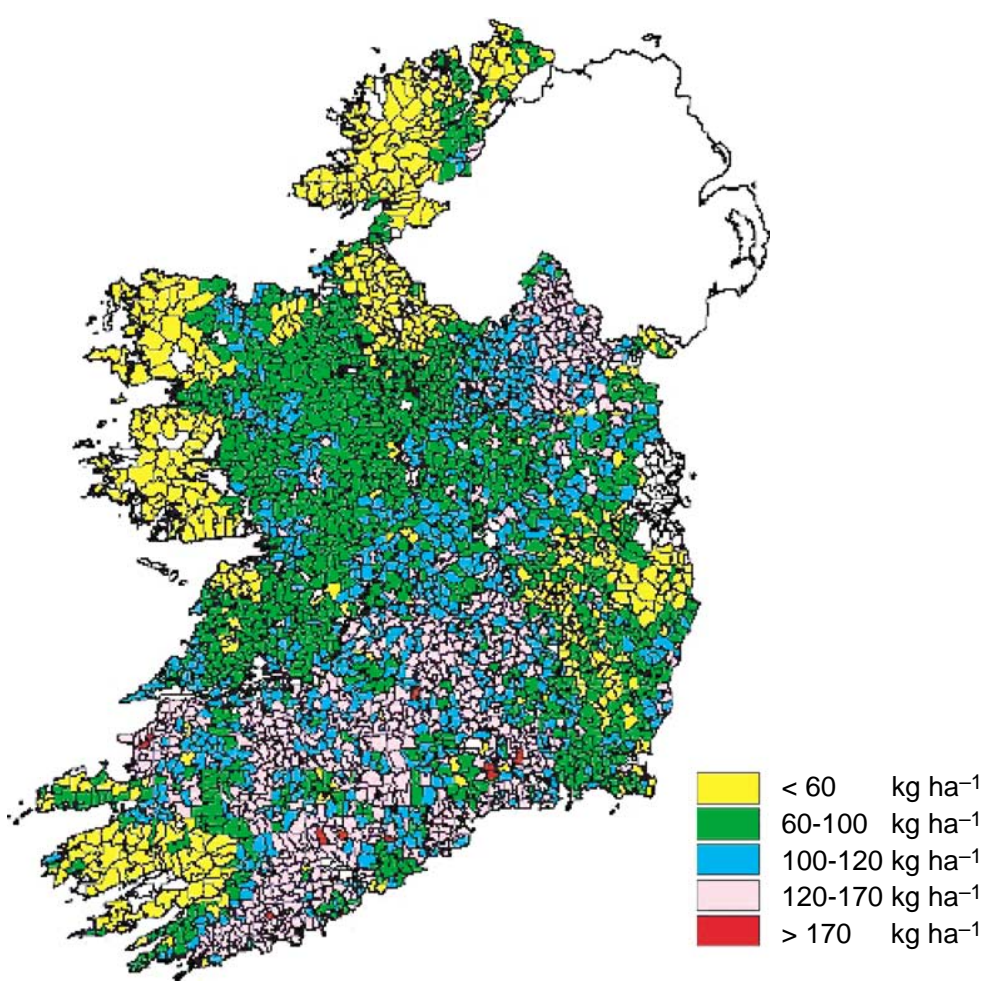

Fig. 2-Distribution of total animal numbers, expressed as total organic N load. Data source: Agricultural Census 2001, Central Statistics Office, Cork.

(Wexford town), the SMD on the 30th June 2002 was calculated as $21.3 \mathrm{~mm}$ for both moderately drained and well-drained soil associations and $16.8 \mathrm{~mm}$ for poorly drained soil associations. With well-drained, moderately drained and poorly drained soil associations covering 49\%, 23\% and $28 \%$ of the land area within this cell, the indicative SMD was calculated as $0.49 \times 21.3+0.23 \times$ $21.3+0.28 \times 16.8=20.1 \mathrm{~mm}$.

While the number of synoptic weather stations (i.e. thirteen) on which this interpolation is based is too small to account for small scale spatial variation of weather variables, particularly precipitation, this interpolation method suffices to demonstrate and compare dominant larger-scale regional patterns. The maps presented in this paper should not, therefore, be interpreted as delineations of sitespecific areas with high or low risk of nutrient losses, but rather as indicative distributions of regional risk factors.

\section{PRESSURES}

Intensity of livestock farming, indicated by animal numbers, was expressed as annual total organic Nload $\left(\mathrm{kg} \mathrm{ha}^{-1} \mathrm{yr}^{-1}\right)$ per District Electoral Division (DED). Data from the Agricultural Census 2001 were used, provided by the Central Statistics Office, Cork. The percentage of land used for tillage, expressed on a DED basis, was adopted from
Coulter et al. (1998). The duration of the grass growth season was calculated as the number of days on which mean air temperature exceeded $6^{\circ} \mathrm{C}$ and soils were not saturated (corresponding to $\mathrm{SMD}>-10 \mathrm{~mm})$ on the same day, as calculated by the Hybrid model (Schulte et al. 2005). The annual maximum SMD was also computed using the Hybrid model.

\section{PATHWAYS}

To illustrate spatial patterns of soil drainage capacity, a weighted drainage factor was calculated for each cell by assigning a weighting of 2, 1 and 0 to well-drained, moderately drained and poorly drained soil associations, respectively. A cell with $100 \%$ well-drained soil associations would score a maximum value of 2 , and a cell with $100 \%$ poorly drained soil associations would score a minimum value of 0 . The weighted drainage factor of cell T02, for example, was calculated as $0.49 \times 2+$ $0.23 \times 1+0.28 \times 0=1.21$, indicating that the soil tended to be moderately drained. Note that the use of these weightings was limited to the illustration of drainage patterns in Fig. 6.

The annual quantity and seasonality of net rainfall, the frequency of intense drainage events and the annual number of trafficable days were all computed by the Hybrid model (Schulte et al. 2005). Intense drainage events were defined as 


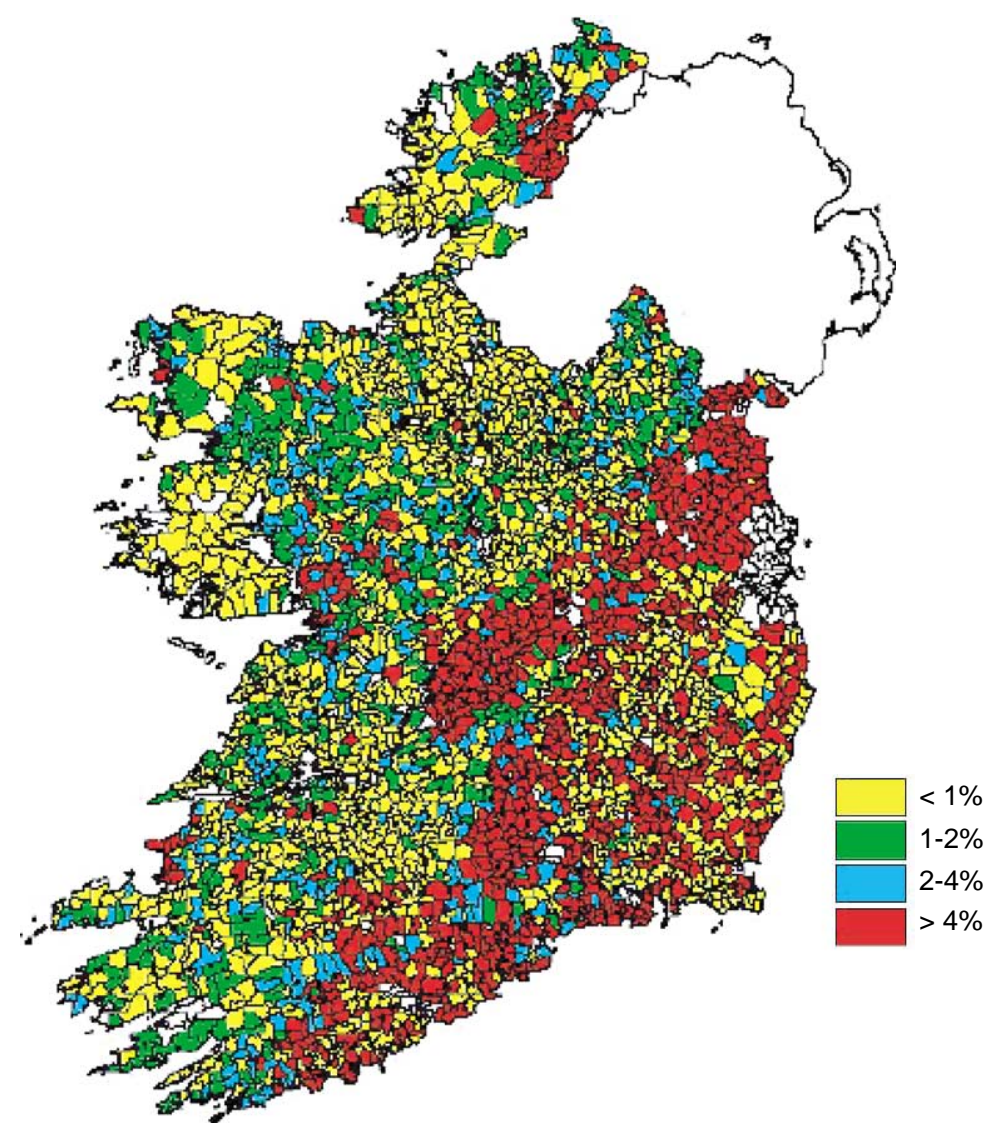

Fig. 3- Distribution of the percentage of land used for tillage on a DED basis. Source: Coulter et al. 1998.

events on poorly drained soils in which $15 \mathrm{~mm}$ or more is drained within a day, while trafficable days were considered days with SMD exceeding $10 \mathrm{~mm}$ (Earl 1997).

\section{RESULTS}

\section{PRESSURES}

Farming intensity

Figure 2 shows the distribution of livestock densities on a DED basis, increasing along a gradient from the north-west to the south and east.

\section{Land use}

Figure 3 illustrates the distribution of tillage farming in Ireland on a DED basis, and a comparison with Figs 6 and 10 shows that tillage operations are largely confined to the better drained soil associations that are workable for substantial parts of the year.

\section{Grass growing season}

Figure 4 shows the regional differences in the median length of the grass growing season for welldrained, moderately drained and poorly drained soil associations, respectively. Two patterns emerge from these maps. Firstly, on well-drained soil associations the number of grass growing days increases from c. 280 days in inland areas to almost 330 days on the western coasts because well-drained soils never reach saturation, and the pattern reflects the number of days above $6^{\circ} \mathrm{C}$, which increases with proximity to the sea. Therefore, this map is indeed very much like Connaughton's (1973) map. Secondly, on poorly drained soils, the growing season ranges from less than 220 days in the north and far west, to c. 250 days on the east coast and in the southern half of the country. This pattern results from both variations in temperature and soil moisture conditions, with the high precipitation in northern and western areas inhibiting the grass to make use of the larger number of days with temperatures above $6^{\circ} \mathrm{C}$ in coastal areas.

The larger map in Fig. 4 combines the three maps into an indicative map of the median duration of the grass growth season across the country, based on the indicative distribution of well-drained, moderately drained and poorly drained soil associations (Fig. 6). It shows that soil drainage capacity has an overriding effect on this duration. With most of the poorly drained soil associations 


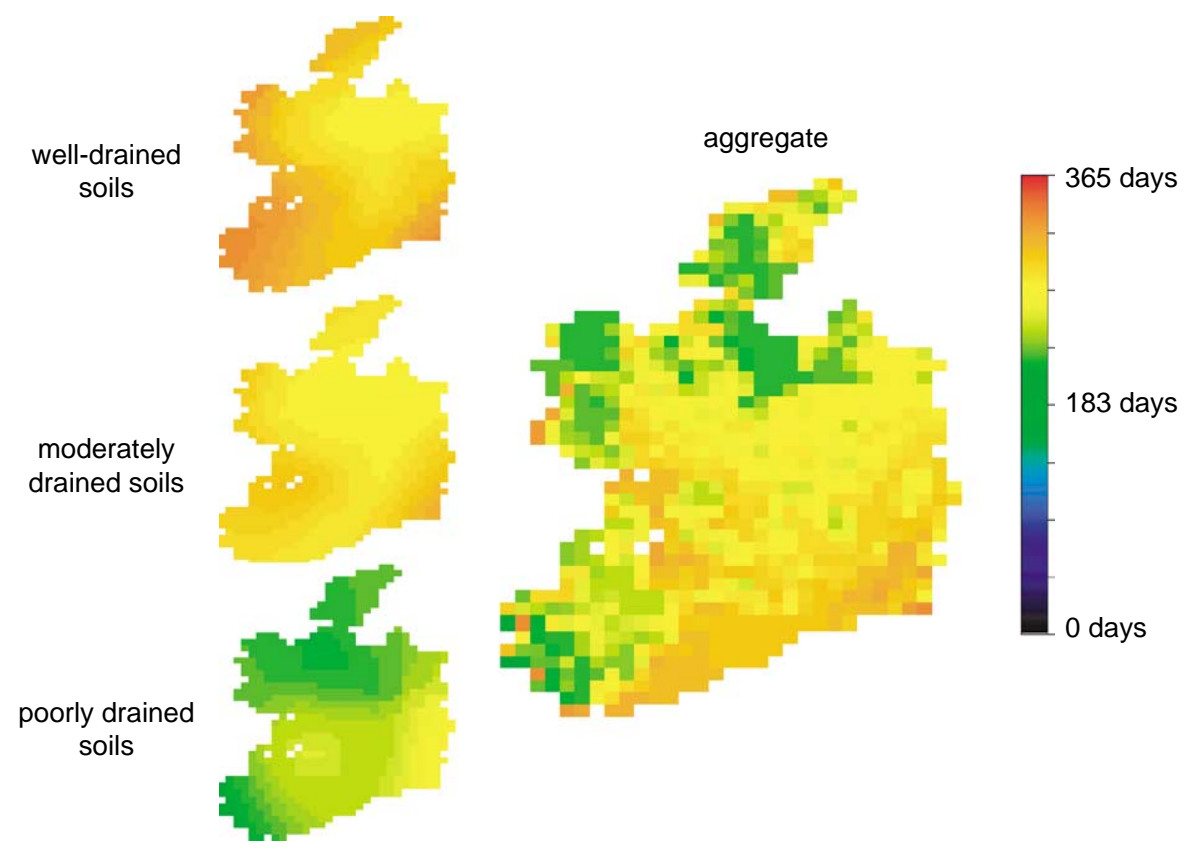

Fig. 4- Length of the grass growing season across Ireland, defined as the number of days with a mean temperature over $6^{\circ} \mathrm{C}$ on which the local soil is not saturated $(\mathrm{SMD}>-10 \mathrm{~mm})$. Small maps illustrate length of growth season individually for well-drained, moderately drained and poorly drained soils. Large map combines these distributions with the indicative drainage map (Fig. 6) to derive an indicative growth season map.

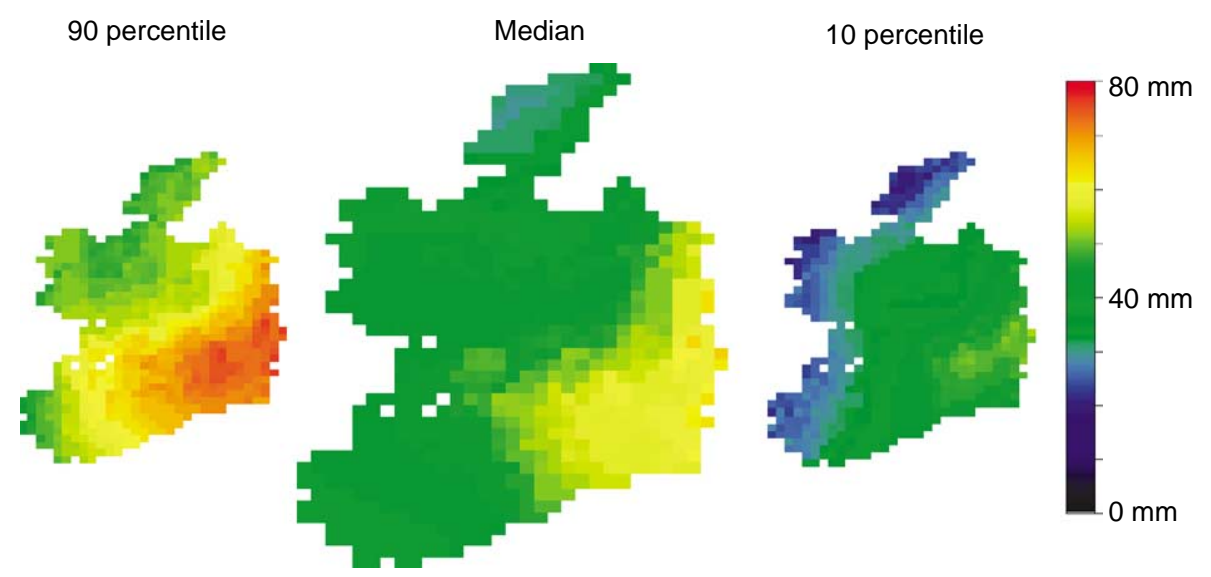

Fig. 5- Map of the maximum soil moisture deficit (SMD) across Ireland. Large map presents median value of the annually maximum SMD. Smaller maps show the 90 percentile and 10 percentile values representing 'dry' and 'wet' years, respectively.

located in the north-western half of the country, longer growing seasons are experienced in welldrained parts of the south and south-east, with differences up to 100 days between regions. On the west coast, long growing seasons are confined to small areas with well-drained soil associations, with soil saturation inhibiting growth on the poorly drained soil associations in the remainder.

\section{Droughts}

Figure 5 shows regional variation of the maximum SMD in a median year, as well as the maximum SMD in a 'dry year' and a 'wet year', respectively. On a scale from $0 \mathrm{~mm}$ to $110 \mathrm{~mm}$, maximum SMDs in a median year range from c. $60 \mathrm{~mm}$ on the east coast to c. $40 \mathrm{~mm}$ on the west coast. Most of these differences are meteorologically induced, as SMDs on poorly drained and well-drained soils converge during the summer months. Although the timing of droughts within the summer season differs from year to year, the regional patterns of droughts shows relatively little variation, increasing along a gradient from the north-west to the south-east. 


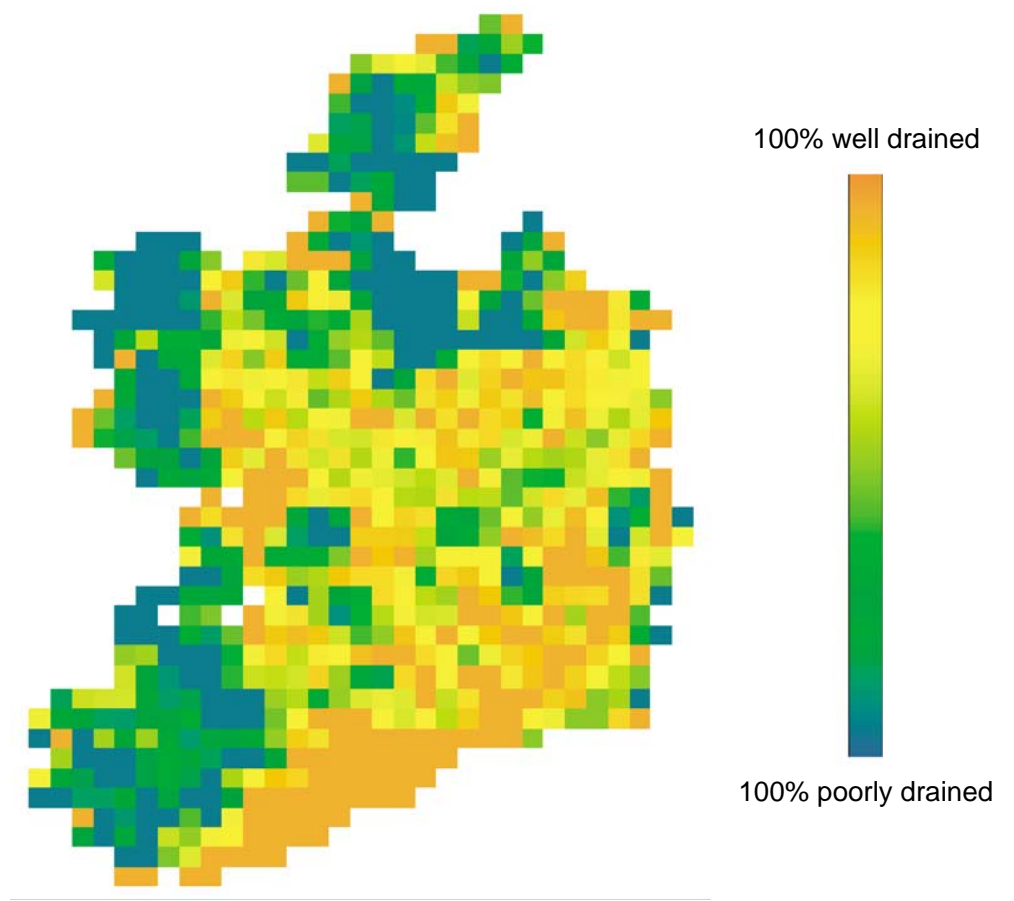

Fig. 6- Indicative drainage map of Ireland, based on the drainage capacity of the dominant mineral soil type of each soil association (Schulte et al. 2005)

\section{PATHWAYS}

Drainage capacity

Figure 6 is an indicative map of the national distribution of the soil drainage. The map shows that most of the well-drained soil associations are located in the east, the south-east, the south and around east Galway. Western areas, the drumlin belt, the Castlecomer plateau and mountainous areas (e.g. Wicklow Mountains) are largely poorly drained, although they contain some smaller areas of well-drained land.

\section{Annual amounts of net rainfall}

Figure 7 presents the median net rainfall patterns across the country, as well as the patterns of the 10 percentile and the 90 percentile of the net rainfall, i.e. the amount of net rainfall exceeded in 9 out of 10 years, and the amount reached once a decade, respectively. The median map shows that spatial variation of net rainfall is more pronounced than the variation of the total rainfall, with median amounts of net rainfall ranging from just over $300 \mathrm{~mm}$ in the east to more than double this value on the west coast. In addition, the 10 percentile and the 90 percentile maps show that the additional amounts of net rainfall in 'wet years' are not as substantial (on average 119\% of the median) as the reduction in volume in 'dry years' (on average 65\% of the median). On average, net rainfall amounts in 'dry years' are just over half the amounts in 'wet years'.
Figure 8 demonstrates the seasonal and geographic distribution of net rainfall volumes for well-drained soil associations, with largely similar volumes computed for moderately and poorly drained soil associations. Largest amounts of net rainfall, i.e. drainage through either infiltration or overland flow, occur during the last three months and the first three months of each year. Full recharge of soil moisture deficits is virtually guaranteed in all areas during this period, with all stations receiving substantial amounts of net rainfall even in the 'driest' of years.

Different patterns emerge during the summer months when drainage is less frequent in eastern and midland areas, with median monthly drainage volumes of $0 \mathrm{~mm}$ in many cases, and small 90percentile volumes. Along western coasts, median monthly drainage volumes remain above $0 \mathrm{~mm}$ throughout the year, indicating drainage throughout the summer months at least every second year.

\section{Intensity of net rainfall}

The geographic and seasonal patterns of intense drainage events (Fig. 9) is largely similar to the patterns of total net rainfall (Fig. 8). Fig. 9 shows the regional and seasonal variation in the frequency of drainage events on poorly drained soils in which $15 \mathrm{~mm}$ or more is drained within a day, mostly through overland-flow. It shows that such events occur most frequently along western and southern coasts, and particularly in the south-west. Few 


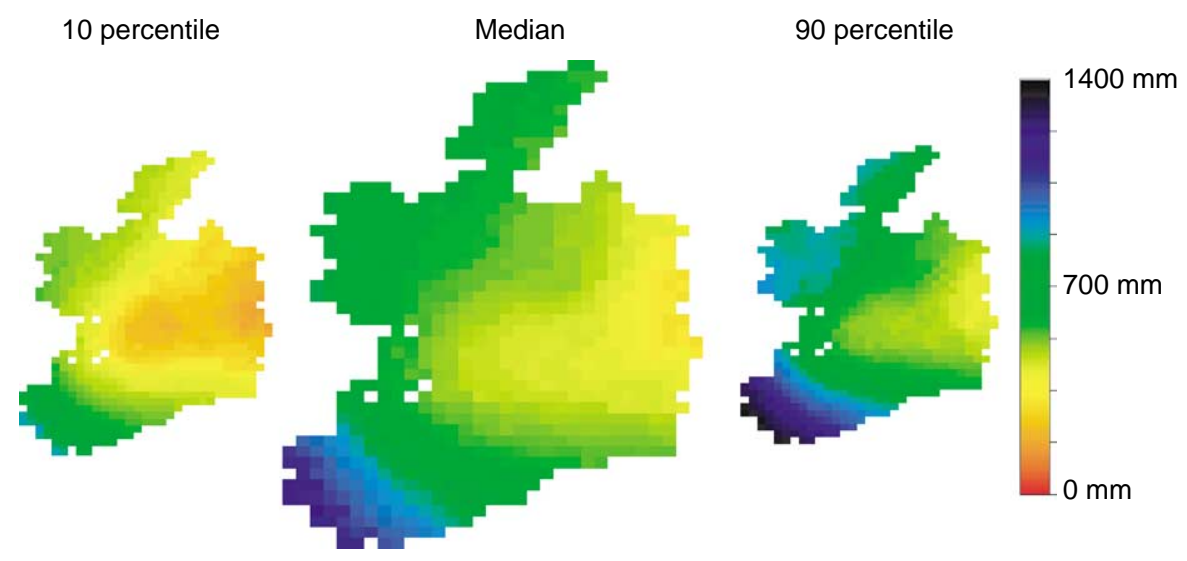

Fig. 7- Map of the distribution of net rainfall across Ireland, defined as precipitation minus actual evapotranspiration. Maps showing 10 percentile, median, and 90 percentile ranges represent 'dry', 'normal' and 'wet' years, respectively.

intense drainage events occur in inland and eastern areas, with this region escaping events altogether once every ten years. Most intense drainage events take place from October to December in all regions, with further high frequencies from January to March. In eastern and midland areas, intense drainage events occur only sporadically during the second and third quarter, with a 90 percentile of about one event per quarter (corresponding to one event per decade for each quarter). Further west, intense drainage events between April and September occur more frequently, up to nine out of ten years in the extreme south-west, giving rise to a substantial variation between years and regions in the risk of phosphorus loss.

\section{Soil trafficability}

Figure 10 presents a map of the number of days that soils have SMDs greater than $10 \mathrm{~mm}$. While these amount to almost half a year on welldrained soils in the east, there are as few as 60 to 80 trafficable days on wet soils in the west. Differences between years are even more pronounced: in 'dry years', the number of trafficable days is higher and almost equal for well-drained and poorly drained soil associations. In 'wet years', however, the number of days on which soils can be safely trafficked on ranges from 120 in the east to 25 or less in the far west. The general north-west to south-east gradients of these maps are similar to the ones reported in Collins and Cummins (1996).

\section{DISCUSSION}

Risk of diffuse nutrient loss to water exists when both pressures from nutrient sources and transport vectors occur at the same location and time. In this paper we have made spatial estimates of the pressures and transport vectors, all of which show considerable variation, between regions, between season, and between years, as a result of spatiotemporal dynamics of agro-meteorological conditions. Fig. 11 illustrates the dominant regional patterns of pressures and pathways of both nitrogen and phosphorus in highly generalised form.

\section{NITROGEN LOSS TO WATER}

Over longer time periods, the interactions of weather and soil conditions define to a large extent the type of farming systems and their intensities that are technically operable and economically viable, and associated nutrient pressures. Neill (1989) related differences in river nitrate concentrations to the fractions of arable land within catchments. However, the picture arising from our work suggests that agro-meteorology, land use and water quality are inter-related. The regional pressure exerted by ploughing largely overlaps with pressures from high livestock densities (Fig. 2), and the associated higher intensities of nutrient inputs. In addition, we have seen that the same region of Ireland commonly experiences the largest SMDs (Fig. 5), which also contribute to nitrate concentrations through mineralisation. The only mediating agrometeorological factor is the longer growing season in the east and south (Fig. 4), provided that this does not encourage application of nutrients at times when utilisation is low.

Pathway factors for nitrogen loss are also pronounced in southern and eastern areas, as large parts of this region have well-drained soil associations (Fig. 6), providing a pathway for nitrate loss to water. Moreover, in the east, the net annual precipitation of $c .300 \mathrm{~mm}$ is enough to ensure full soil recharge each winter and thus provide a pathway for nitrogen to be transported 


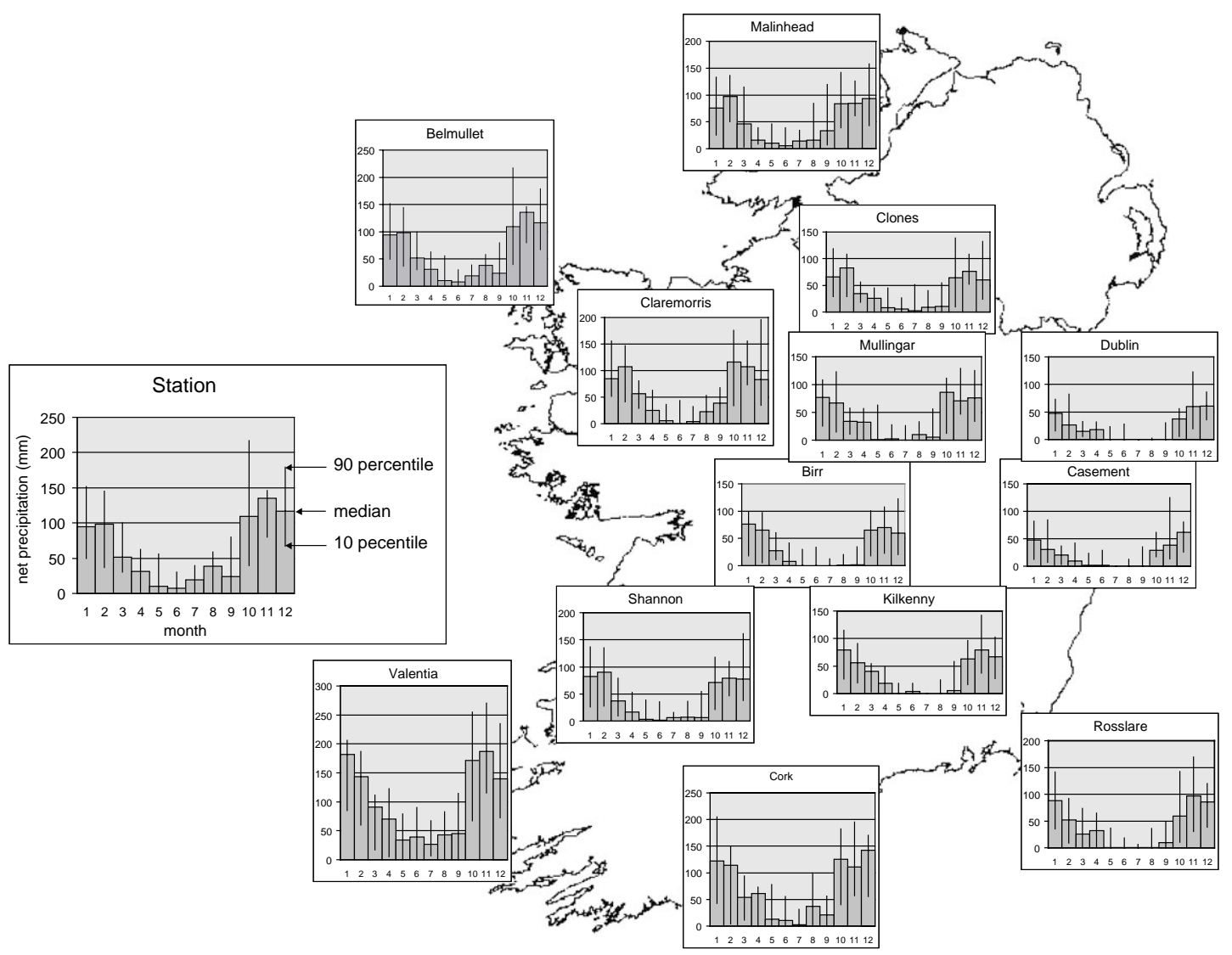

Fig. 8- Seasonal and regional distribution of net rainfall $(\mathrm{mm})$. Bars show median values; extremities of lines indicate 10 percentile and 90 percentile values.

below the rooting zone, but this $300 \mathrm{~mm}$ hardly dilutes nitrate concentrations in water leading to low critical loads for nitrate leaching. The potential implications of this are illustrated in Fig. 12, in which total nitrogen loss $\left(\mathrm{kg} \mathrm{N} \mathrm{ha} \mathrm{yr}^{-1}\right)$ is converted into nitrate concentrations ( $\mathrm{mg}$ nitrate- $\mathrm{N}$ $1^{-1}$ ) for two levels of net annual rainfall (following Worrall and Burt 2001), representative of net rainfall amounts in two contrasting regions, i.e. Dublin and Cork.

Near Dublin, with a median effective rainfall of $318 \mathrm{~mm}$, N-leaching losses as little as $36 \mathrm{~kg} \mathrm{ha}^{-1}$ per year could lead to a breach of the Maximum acceptable concentration (MAC). In 'dry years', when effective rainfall is less then $200 \mathrm{~mm}$, the critical N-load leached could be as low as $21 \mathrm{~kg} \mathrm{ha}^{-1}$, whereas $45 \mathrm{~kg} \mathrm{ha}^{-1}$ would need to be lost before the MAC is breached in 'wet years'. In Cork, similar nitrogen loads leached could result in much lower nitrate concentrations, since net rainfall here is more than twice as high. Leaching losses as high as 91,69 , and $113 \mathrm{~kg} \mathrm{ha}^{-1}$ could cause a breach of the MAC in median, dry and wet years, respectively.

In this light, it is not surprising that the highest nitrate concentrations in rivers are found in rivers draining catchments in the east and the south of the country (Fig. 13; taken, with permission, from Environmental Protection Agency 2004), i.e. where both pressures and pathways for nutrient loss coincide. Eutrophication of estuaries shows similar spatial patterns (Environmental Protection Agency 2004).

\section{PHOSPHORUS LOSS TO WATER}

Agro-meteorological factors alone suggest that risk of phosphorus loss is highest in western and northern areas, where poorly drained soils carry water surpluses for large parts of the year and supply a pathway for phosphorus loss. In addition, these areas have the highest incidences of intense drainage events (Fig. 9) and the shortest grass growth periods (Fig. 4).

McGarrigle et al. (2002) produced a map of Q-values - a biological indicator of Irish rivers strongly correlated with median P-levels. This indicates that phosphorus concentrations in rivers are highest in eastern and south-eastern regions, as well as in parts of counties Cavan, Monaghan, Cork and Limerick in the north-western region. These areas largely correspond to those with the highest 


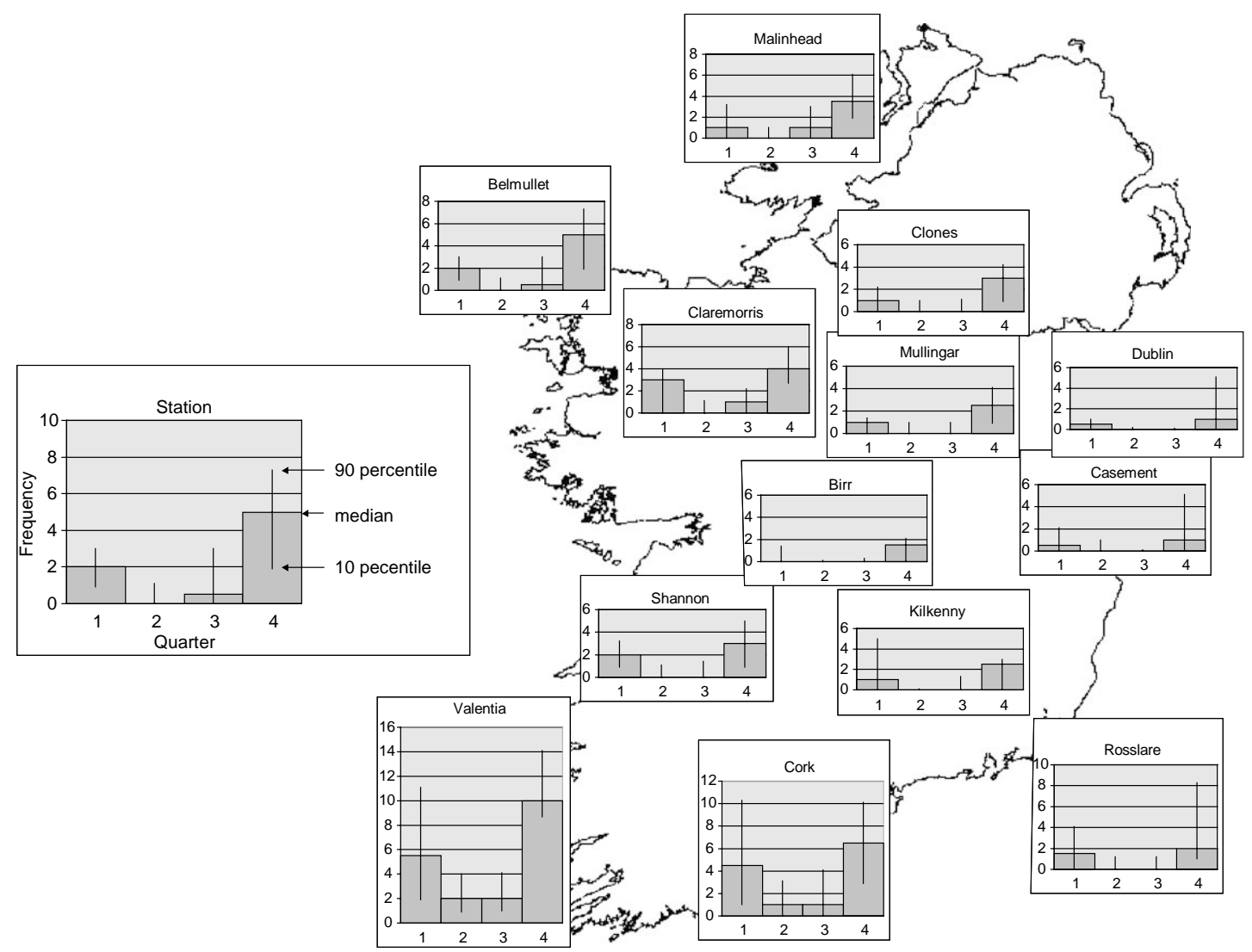

Fig. 9- Seasonal and regional distribution of the incidence of intense rainfall events ( $>15 \mathrm{~mm}$ per day). Bars show median values, extremities of lines indicate 10 percentile and 90 percentile values.

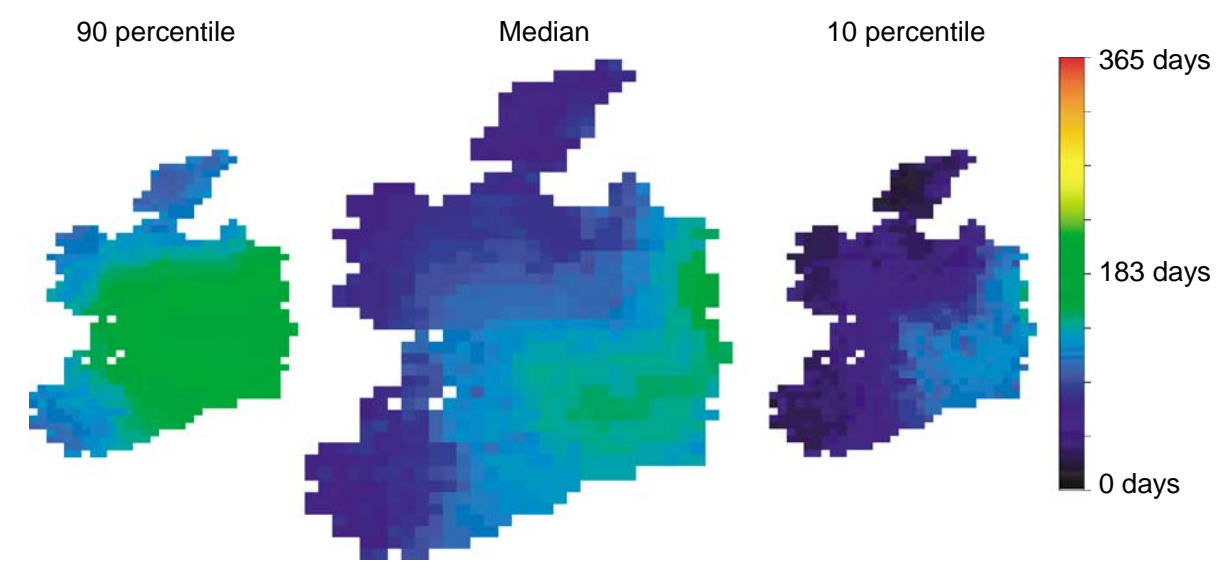

Fig. 10-Distribution of the number of days on which soils have a soil moisture deficit in excess of $10 \mathrm{~mm}$. Maps showing 90 percentile, median, and 10 percentile maps represent 'dry', 'normal' and 'wet' years, respectively.

stocking densities (Fig. 2). In terms of the pressurepathway-receptor concept (Fig. 1), this suggests that, although pathways for phosphorus loss are most prevalent in northern and western areas, the absence of significant pressures in most of the north-west explains the generally good river water quality in this region. Exceptions to this generalisation should be noted. Not only are high nutrient pressures widespread in parts of the western counties mentioned above (Fig. 2); at smaller geographical scales, high nutrient pressures may occur locally and temporally. For example, in a detailed examination of water quality in the Lough Mask catchment (west of Ireland), Donohue et al. 


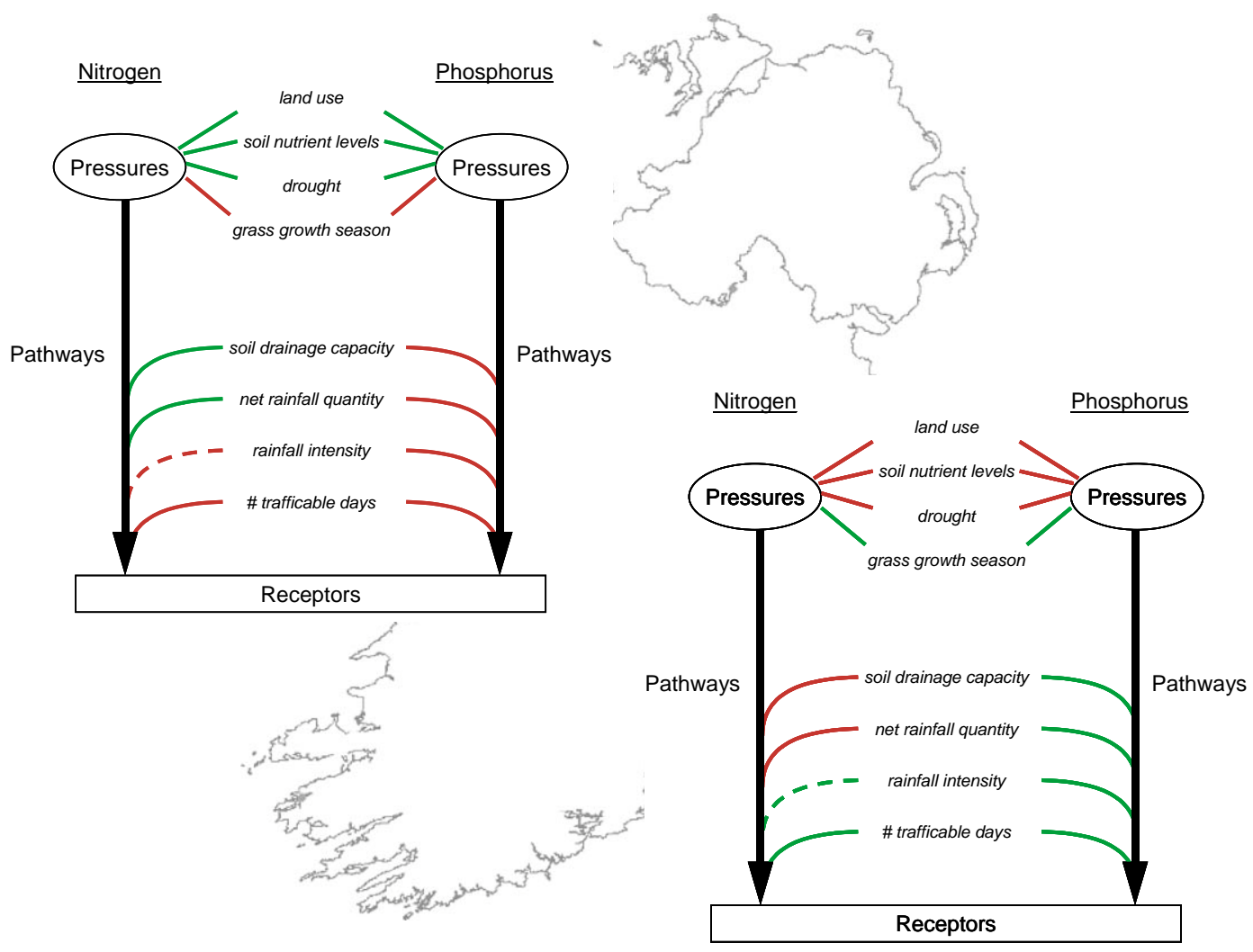

Fig. 11-Conceptual and highly generalised summary of regional contrasts of pressure and pathway factors (compare with Fig. 1). Red lines indicate factors that add to risk of nutrient loss at a regional level, while green lines indicate factors that, by comparison, ameliorate risks.

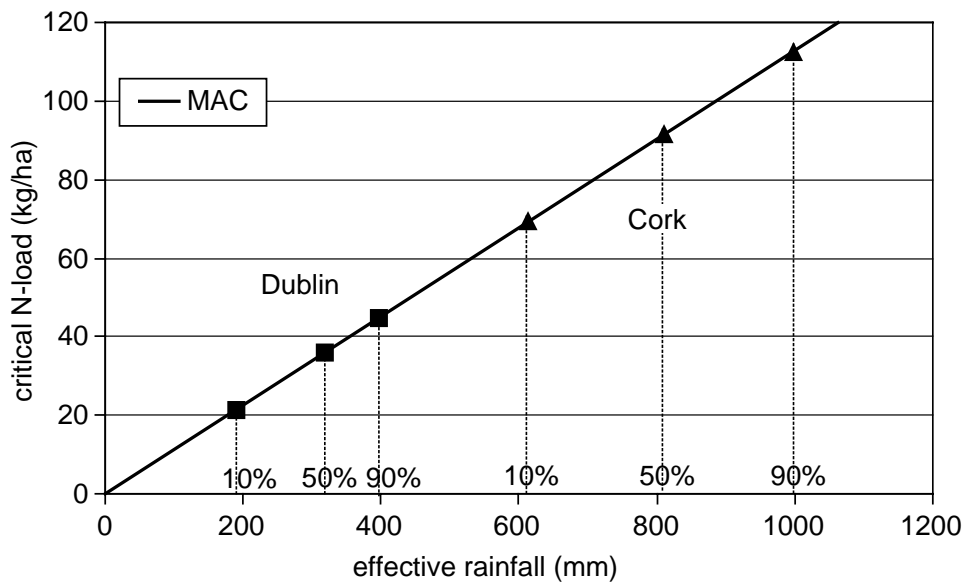

Fig. 12- Impact of net rainfall on the critical N-load, i.e. the amount of N-leaching that gives rise to breaches of the maximum allowable concentration (MAC).

(2005) identified intensive grasslands and urban areas as local sources of nutrient loads. Also in the west of Ireland, temporal and localised increases in nutrient pressures were observed after both clearfelling and fertilisation of forests on blanket peat, resulting in large, temporal increases in molybdate-reactive phosphorus in surface waters (Cummins and Farrell 2003).

Conversely, although pathways for nutrient loss are less pronounced in eastern and southern regions, generally large phosphorus pressures here give rise to more frequent breaches of water 

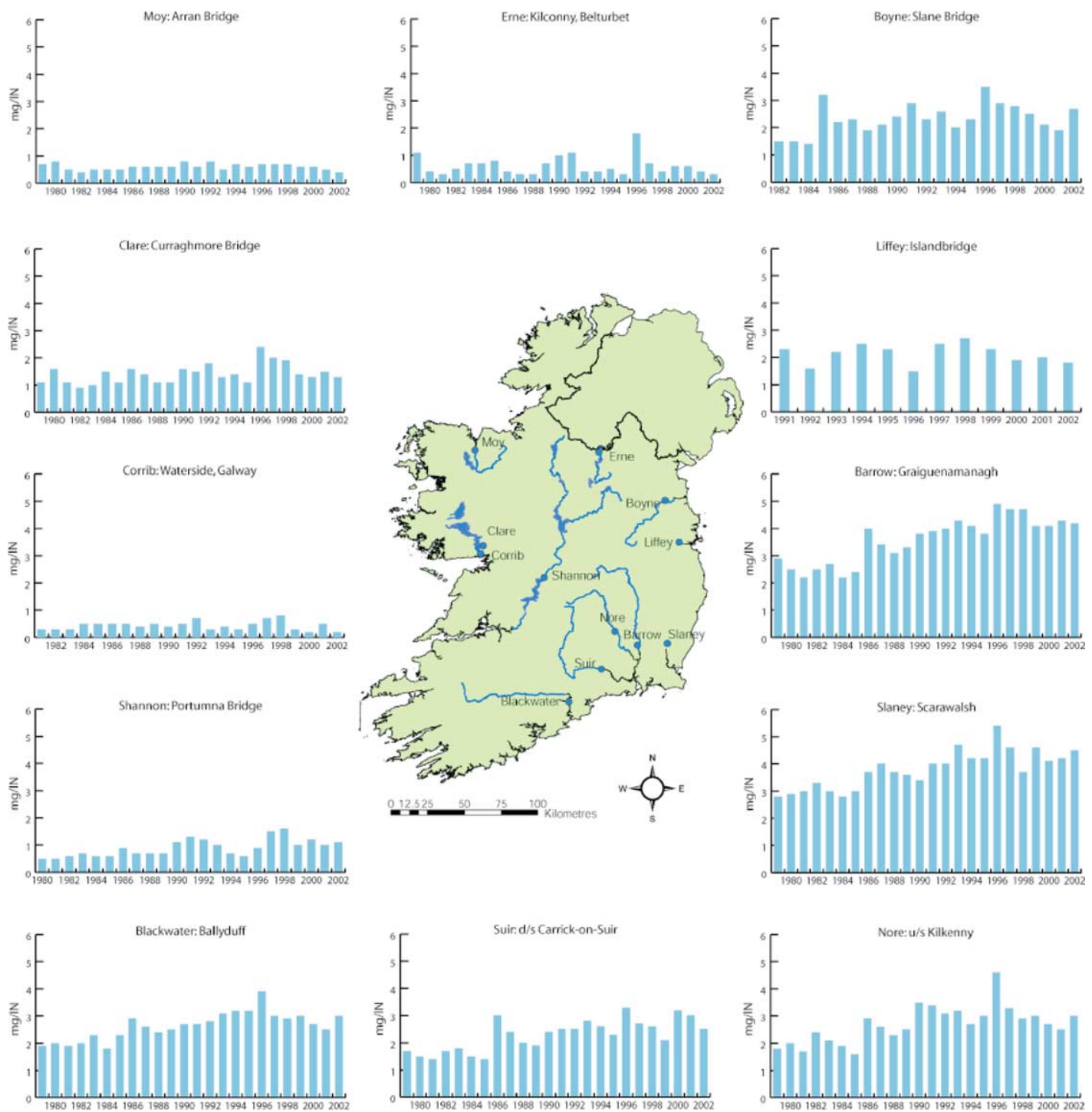

Fig. 13 - Nitrate-nitrogen concentrations $\left(\mathrm{mg}^{-1}\right)$ over time of a number of large rivers in Ireland. Reproduced with the permission of the Environmental Protection Agency (2004).

quality standards. This agrees with the findings by Daly et al. (2002), who related phosphorus concentrations in a number of Irish rivers to land use, soil type and soil test $\mathrm{P}$ levels. Whilst soil hydrology delineated wet and dry areas within catchments and influenced $\mathrm{P}$ concentrations in rivers, most of the areas at risk of $\mathrm{P}$ loss to water were delineated by dry, well-drained mineral soils that have high $\mathrm{P}$ reserves (and high $\mathrm{P}$ inputs) compared to organic soils in poorly drained areas.

\section{IMPLICATIONS FOR REGIONAL MANAGEMENT OF AGRICULTURE}

These regional differences in pressures and pathways of losses of nitrogen and phosphorus require that farm practices be customised to local risk of nutrient loss to water. With pathways for phosphorus loss present almost year-round in most of the north-western half of the country, build-up of the currently low phosphorus pressures should be prevented or ameliorated where pressures are already high. In the south-eastern half, further proliferation of both pressures (of both nitrogen and phosphorus) and pathways should be prevented, and in particular the temporal coincidence of both. Since, in practical terms, this implies that nutrients should not be applied at times that loss pathways are present, the most serious challenge in this light is the significant discrepancy in most areas between the length of the grass growth season, during which nutrients can be utilised by the growing crop, and the number of days on which soils can be safely trafficked on. This means that full utilisation of the seasonal growth potential would require nutrients to be applied, and 
herbage to be utilised, at times when loss pathways are present, i.e. when soils are wet. This would not only pose an immediate risk of nutrient losses, but in addition may contribute to the further proliferation of loss pathways through compaction (Drewry et al. 2000).

In addition, substantial between-year variation in agro-meteorological conditions was observed. Whilst the year-to-year variation in the length of the growth season was small (not shown), in many areas the length of the grazing season, i.e. the number of days on which soils had SMDs in excess of $10 \mathrm{~mm}$, varied by a factor of two between 'dry' and 'wet' years. Comparable differences between 'dry' and 'wet' years were identified for the maximum SMD ('droughts') and incidences of intense rainfall events. Similarly, amounts of rainfall varied significantly among years, which impacts directly to varying degrees of dilution of nitrate concentrations. As a result, critical N-loads may be expected to fluctuate between years.

\section{FURTHER DEVELOPMENTS}

The geographical patterns in risk of nutrient losses to water have been identified and discussed at a large scale, with a low spatial resolution. This resolution is primarily the result of the small number of synoptic weather stations, which are the basis of the spatial patterns of weather conditions. This number is particularly small for precipitation, the amounts of which vary considerably with local topography. The agrometeorological maps presented in this paper, much like many of the maps reported in Collins and Cummins (1996), therefore illustrate largescale, nationwide meteorological patterns only, and their interpretation should reflect this coarse spatial resolution.

Soil characteristics, specifically drainage capacity, were accounted for on a finer spatial scale, as these were based on the General Soils Map. However, this classification is based on the drainage capacity of the dominant mineral soil type of each soil association only, and this does not allow the drainage capacity of individual fields or farms to be identified: areas of well-drained land may well contain pockets of poorly drained soils and viceversa. In addition, the drainage capacity of soils may be altered by farm practices, e.g. increase with artificial drainage and decrease by compaction (Schulte et al. 2005).

Following from this, the spatial patterns identified in this paper should not be interpreted as quantitative delineations of areas with different risk of nutrient losses. Such delineations require a GIS-approach to quantify aspects of soil type such as drainage status at a much finer spatial scale, similar to the national datasets currently being developed by the Spatial Analysis Group at Teagasc, which is delivering these data to the EPA for the Water Framework Directive. These datasets include a national soil parent material map, a national soil map (developed using predictive modelling), a national land cover map and a national habitat indicator map. The maps are at a working scale of 1:50,000-1:100,000. In addition, it requires a higher spatial resolution of weather observations, in particular of precipitation, which is the subject of current research.

\section{ACKNOWLEDGEMENTS}

The authors gratefully acknowledge Met Éireann for providing all meteorological data and for proofreading the manuscript.

\section{REFERENCES}

Addiscott, T.M. 1996 Fertilisers and nitrate leaching. In R.E. Hester and R.M. Harrison (eds), Agricultural chemicals and the environment. Issues in environmental Science and technology no. 5. Cambridge. The Royal Society of Chemistry.

Ahuja, L.R., Sharpley, A.N, Yamamoto, M. and Menzel, R.G. 1981 The depth of rainfall-runoff-soil interaction as determined by ${ }^{32} \mathrm{P}$. Water Resources Research 17, 969-74.

Ansell, J. and Wharton, F. (eds) 1992 Risk: Analysis, Assessment and Management. Chichester. John Wiley \& Sons.

Barraclough, D., Hyden, M.J. and Davies, G.P. 1983 Fate of fertiliser nitrogen applied to grassland. I. Field leaching results. Journal of Soil Science 34, 48397.

Beever, D.E., Dhanoa, M.S., Losada, H.R., Evans, R.T., Cammell, S.B. and France, J. 1986 The effect of forage species and stage of harvest on the process of digestion occurring in the rumen of cattle. British Journal of Nutrition 56, 439-54.

Brereton, A.J. and Hope-Cawderry, M. 1988 Drumlin soils - the depression of herbage yield by shallow water table depth. Irish Journal of Agricultural Research 27, 167-78.

Burke, J.I., Brereton, A.J., O'Kiely, P.O. and Schulte, R.P.O. 2004 Weather and crop production. In T. Keane and J.F. Collins (eds), Climate, weather and Irish agriculture. 2nd edn. Dublin. Joint Working Group on Applied Agricultural Meteorology.

Burt, T.P. 2003 Monitoring change in hydrological systems. The science of the total environment $\mathbf{3 1 0}$, $9-16$.

Collins, J.F. and Cummins, T. (eds) 1996 Agroclimatic atlas of Ireland. Dublin. Joint Working Group on Applied Agricultural Meteorology.

Connaughton, M.J. 1973 The grass growing season in Ireland. Agrometeorological Memorandum no. 5. Dublin. Met Éireann. 


\section{BIOLOGY AND ENVIRONMENT}

Coulter, B.S. (ed.) 2004 Nutrient and trace element advice for grassland, tillage, vegetable and fruit crops. 2nd edn. Dublin. Teagasc.

Coulter, B.S., McDonald, E.J. and Lee, J. 1998 Enhancing and visualising data on soils, land use and the environment. End of project report. Dublin. Teagasc. http://www.teagasc.ie/research/ reports/environment/4104/eopr-4104.pdf

Cummins, T. and Farrell, E.P. 2003 Biochemical impacts of clearfelling and reforestation on blanket peatland streams I. phosphorus. Forest Ecology and Management 180, 545-55.

Daly, K., Jeffrey, D. and Tunney, H. 2001 The effect of soil type on phosphorus sorption capacity and desorption dynamics in Irish grassland soils. Soil Use and Management 17, 12-20.

Daly, K., Mills, P., Coulter, B. and McGarrigle, M. 2002 Modelling phosphorus concentrations in Irish rivers using land use, soil type and soil phosphorus data. Journal of Environmental Quality 31, 590-9.

Diamond, J. and Sills, P. 2001 Soil water regimes. End of project report. Dublin. Teagasc.

Donohue, I., Styles, D., Coxon, C. and Irvine, K. 2005. Importance of spatial and temporal patterns for assessment of risk of diffuse nutrient emissions to surface water. Journal of Hydrology 304, 183-92.

Doody, D. 2004 Flow effects on phosphorus loss in overland flow from agricultural grassland soil. Unpublished PhD thesis, University of Limerick.

Drewry, J.J., Littlejohn, R.P. and Paton, R.J. 2000 A survey of soil physical properties on sheep and dairy farms in southern New Zealand. New Zealand Journal of Agricultural Research 43, 251-8.

Earl, R. 1997 Prediction of trafficability and workability from soil moisture deficit. Soil and Tillage Research 40, 155-68.

Environmental Protection Agency 2004 Ireland's Environment 2004. Wexford. Environmental Protection Agency.

Gardiner, M.J. and Radford, T. 1980 General soil map of Ireland. Dublin. Teagasc.

Garwood, E.A. and Williams, T.E. 1967 Soil water use and growth of a grass sward. Journal of agricultural Science 68, 281-92.

Garwood, E.A. and Ryden, J.C. 1986 Nitrate loss through leaching and surface runoff from grassland: effects of water supply, soil type and management. In H.G. van der Meer, J.C. Ryden and G.C. Ennik (eds), Nitrogen fluxes in intensive grassland systems, 99-113. Dordrecht. Martinus Nijhoff.

Hamilton, J.E.M., Lennon, P. and O'Donnell, B. 1988 Objective analysis of monthly climatological fields of temperature, sunshine, rainfall percentage and rainfall amount. Journal of Climatology 8, 109-24.

Haygarth, P.M. and Jarvis, S.C. 1997 Soil derived phosphorus in surface runoff from grazed grassland lysimeters. Water Research 31, 140-8.

Haygarth, P.M., Condron, L.M., Heathwaite, A.L., Turner, B.L. and Harris, G.P. 2005 The phosphorus transfer continuum: linking source to impact with an interdisciplinary and multi-scaled approach. Science of the Total Environment 344, 5-14.
Heathwaite, A.L. and Dils, R.M. 2000 Characterising phosphorus loss in surface and subsurface hydrological pathways. Science of the Total Environment 251/252, 523-38.

Heathwaite, A.L., Fraser, A.I., Johnes, P.J., Hutchins, M., Lord, E. and Butterfield, D. 2003 The Phosphorus Indicators Tool: a simple model of diffuse P loss from agricultural land to water. Soil Use and Management 19, 1-11.

Herlihy, M. 1979 Nitrogen mineralisation in soils of varying texture, moisture and organic matter, I. Potential and Experimental values in fallow soils. Plant and Soil 53, 255-67.

Holden, N.M. and Brereton, A.J. 2002 An assessment of the potential impact of climate change on grass yield in Ireland over the next 100 years. Irish Journal of Agricultural and Food Research 41(2), 213-26.

Holden, N.M., Brereton, A.J., Fealy, R. and Sweeney, J. 2003 Possible change in Irish climate and its impact on barley and potato yields. Agricultural and Forest Meteorology 116, 181-96.

Jordan, P., Menary, W., Daly, K., Kiely, G., Morgan, G., Byrne, P. and Moles, R. 2005 Patterns and processes of phosphorus loss from Irish grassland soils to rivers-integration of laboratory and catchment studies. Journal of Hydrology 304, 20-34.

Keane, T. 2001 Meteorological Data-Types and Sources. In N.M. Holden (ed.), Agro-Meteorological Modelling-Principles, Data and Application. Dublin. Joint Working Group on Applied Agricultural Meteorology.

Kurz, I. 2002 Phosphorus exports from agricultural grassland in overland flow and drainage water. Unpublished $\mathrm{PhD}$ thesis, Department of Geology, Trinity College, Dublin.

Kurz, I., Coxon, C., Tunney, H. and Ryan, D. 2005 Effects of grassland management practices and environmental conditions on nutrient concentrations in overland flow. Journal of Hydrology 304, 35-50.

McColl, R.H.S. 1979 Factors affecting downslope movement of nutrients in hill pasture. Progress in Water Technology 11, 271-85.

McElwain, L. and Sweeney, J. 2003 Climate change in Ireland-recent trends in temperature and precipitation. Irish Geography 36 (2), 97-111.

McGarrigle, M.L. 2005 Water quality in Irelanddiffuse agricultural eutrophication-a key problem. In E.J. Dunne, K.R. Reddy and O.T. Carton (eds), Nutrient management in agricultural watersheds: a wetlands solution, 15-17. Wageningen, The Netherlands. Wageningen Academic Publishers.

McGarrigle, M.L., Bowman, J.J., Clabby, K.J., Lucey, J., Cunningham, P., MacCárthaigh, M., Keegan, M., Cantrell, B., Lehane, M., Clenaghan, C. and Toner, P.F. 2002 Water quality in Ireland 1998-2000. 2nd edn. Wexford. Environmental Protection Agency.

Nash, D. and Murdoch, C. 1997 Phosphorus in runoff from a fertile dairy pasture. Australian Journal of Soil Research 35, 419-29.

Nash, D., Hannah, M., Halliwell, D. and Murdoch, C. 2000 Factors affecting phosphorus export 


\section{Agriculture, METEOROLOGy AND WATER QUALITY IN IRELAND}

from a pasture-based grazing system. Journal of Environmental Quality 29, 1160-6.

Neill, M. 1989 Nitrate concentrations in river waters in the south-east of Ireland and their relationship with agricultural practice. Water Research 23 (11), $1339-55$.

Neill, M. 2004 River quality in south-east Ireland, 2003. Wexford. Environmental Protection Agency, Regional Water Laboratory, Kilkenny.

O'Connell, K. and Humphreys, J. 2005 Accounting for nitrogen mineralisation in nitrogen fertiliser advice. In R.P.O. Schulte, K. Richards, J. Finn and N. Culleton (eds), The science of Ireland's rural environment: current research highlights from Johnstown Castle. Johnstown Castle, Wexford. Teagasc.

Pote, D.H., Daniel, T.C., Nichols, D.J., Sharpley, A.N., Moore, P.A. Jr., Miller, D.M. and Edwards, D.R. 1999 Relationship between phosphorus levels in three Ultisols and phosphorus concentrations in runoff. Journal of Environmental Quality 28, 170-5.

Quinton, J.N., Catt, J.A. and Hess, T.M. 2001 The selective removal of phosphorus from soil: is event size important? Journal of Environmental Quality 30, $538-45$.

Rearte, D.H. 2005 New insights into the nutritional value of grass. In J.J. Murphy (ed.), Utilisation of grazed grass in temperate animal systems. Proceedings of a satellite workshop of the XXth International Grassland Congress, July 2005, Cork.

Richards, K. 1999 Sources of nitrate leached to groundwater in grasslands of Fermoy, Co. Cork. Unpublished $\mathrm{PhD}$ thesis, Trinity College Dublin.

Ryan, M.G., O'Toole, P. and Farrell, E.P. 1998 The influence of drought and natural re-wetting on nitrogen dynamics in a coniferous ecosystem in Ireland. Environmental Pollution 102, 445-51.

Ryan, M. and Fanning, A. 1999 Leaching studies in lysimeter units. End of Project Report 3856. Dublin. Teagasc.

Scholefield, D., Lockyer, D.R., Whitehead, D.C. and Tyson, K.T. 1991 A model to predict transformations and losses of nitrogen in UK pastures grazed by beef cattle. Plant and Soil 132, $165-77$.

Scholefield, D., Tyson, K.C., Garwood, E.A., Armstrong, A.C., Hawkins, J. and Stone, A.C. 1993 Nitrate leaching from grazed grassland lysimeters: effects of fertiliser input, field drainage, age of sward and patterns of weather. Journal of Soil Science 44, 601-13.

Schulte, R.P.O., Diamond, J., Finkele, K., Holden, N.M. and Brereton, A.J. 2005 Predicting the soil moisture conditions of Irish grasslands. Irish Journal of Agricultural and Food Research 44, 95-110.
Stapleton, L., Lehane, M. and Toner, P. (eds) 2000 Ireland's environment: a Millenium report. Wexford. Environmental Protection Agency.

Thomsen, I.K and Christensen, B.T. 1998 Cropping system and residue management effects on nitrate leaching and crop yields, Agriculture, Ecosystems and Environment 68, 73-84.

Tiessen, H., Stewart, J.W.B. and Moir, J.O. 1983 Changes in organic and inorganic phosphorus composition of two grassland soils and their particle size fractions during 60 to 90 years. Journal of Soil Science 34, 815-23.

Toner, P., Bowman, J., Clabby, K., Lucey, J., McGarrigle, M., Concannon, C., Clenaghan, C., Cunningham, P., Delaney, J., O'Boyle, S., MacCárthaigh, M., Craig, M. and Quinn, R. 2005 Water quality in Ireland, 2001-2003. Wexford. Environmental Protection Agency.

Tunney, H., Coulter, B., Daly, K., Kurz, I., Coxon, C., Jeffrey, D., Mills, P., Kiely, G. and Morgan, G. 2000 Quantification of phosphorus loss to water due to soil P desorption. Final Report. Environmental Monitoring R\&D Report Series no. 6. Wexford. Environmental Protection Agency.

Tyson, K.C., Scholefield, D., Jarvis, S.C. and Stone, A.C. 1997 A comparison of animal output and nitrogen leaching losses recorded from drained fertilized grass and grass/clover pasture. Journal of Agricultural Science 129, 315-23.

Uusitalo, R., Turtola, E., Kauppila, T. and Lilja, T. 2001 Particulate phosphorus and sediment in surface runoff and drainflow from clayey soils. Journal of Environmental Quality 30, 589-95.

Webster, C.P. and Dowdell, R.J. 1984 Effect of drought and irrigation on the fate of nitrogen applied to cut permanent grass swards in lysimeters: leaching losses. Journal of Science Food and Agriculture 35, 1105-11.

Webster, C.P. and Dowdell, R.J. 1986 Effect of drought and irrigation on the fate of nitrogen applied to cut permanent grass swards in lysimeters: nitrogen balance sheet and the effect of sward destruction and ploughing on nitrogen mineralisation. Journal of Science Food and Agriculture 37, 845-54.

Whitehead, D.C. 1995 Grassland nitrogen. Wallingford, UK. CAB International.

Woledge, J. and Dennis, W.D. 1982 The effect of temperature on photosynthesis of ryegrass and white clover leaves. Annals of Botany 50, 25-35.

Worrall, F. and Burt, T.P. 2001 Inter-annual controls on nitrate export from an agricultural catchmenthow much land-use change is safe? Journal of Hydrology 243, 228-41. 